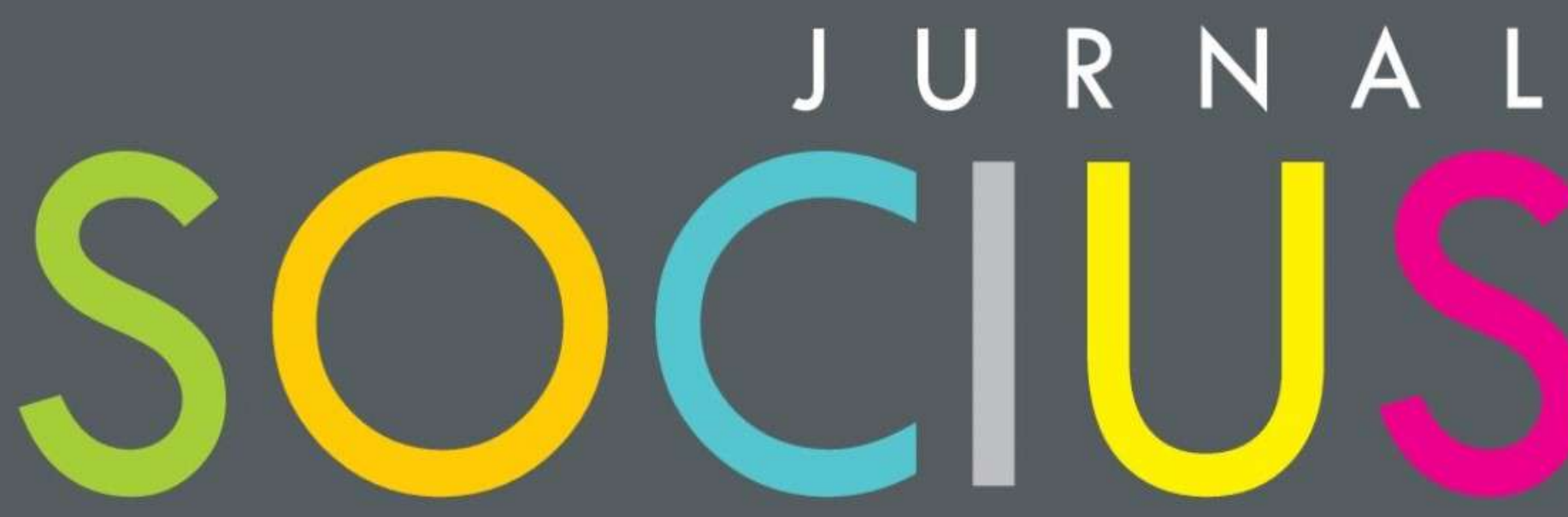

Journal of Sociology Research and Education

DITERBITKAN OLEH :

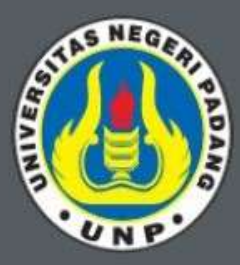

LABOR JURUSAN SOSIOLOGI FAKULTAS ILMU SOSIAL UNIVERSITAS NEGERI PADANG

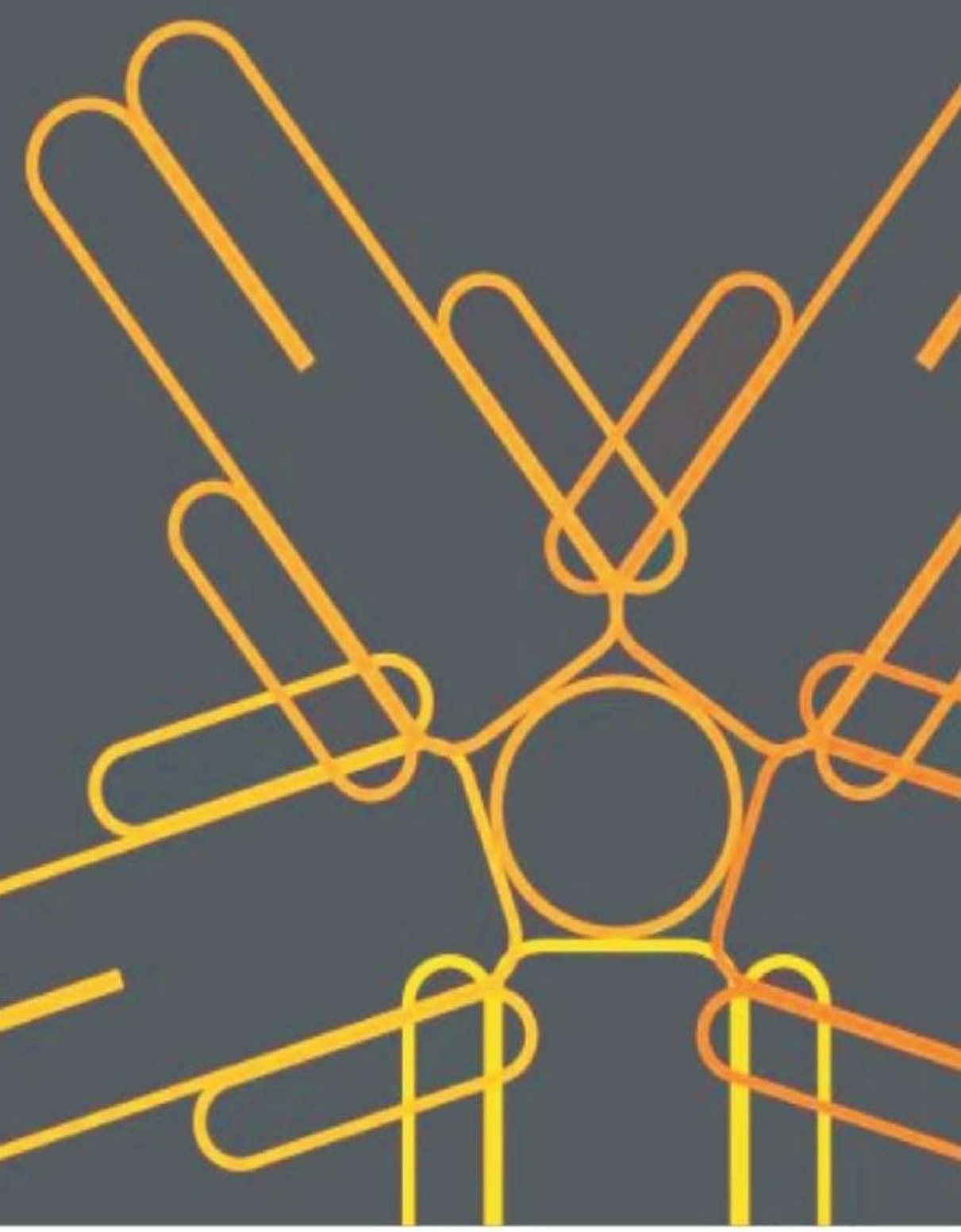




\section{SOCIUS}

Vol. 4, No.1, Th. 2017

ISSN: 2356-4180 (cetak)

2442-8663 (online)

REDAKSI JURNAL SOCIUS

Ketua Dewan Penyunting : Dr. Erianjoni, S.Sos., M.Si

Wakil Ketua Dewan Penyunting : Selinaswati, S.Sos., M.A., Ph.D.

\section{Dewan Penasehat:} Prof. Dr. Syafri Anwar, M.Pd (Universitas Negeri Padang) Prof. Dr. Mestika Zed, MA. (Universitas Negeri Padang) Prof. Dasman Lanin, M.Pd., Ph. D. (Universitas Negeri Padang) Bakhrul Khair Amal, SE.,M.Si. (Universitas Negeri Medan)

Prof. Dr. Ferdinand Kerebungu, M.Si. (Universitas Negeri Manado) Dr.rer.nat. Nurhadi, S.Ant., M. Hum. (Universitas Negeri Solo)

Drs. Emizal Amri, M.Pd., M.Si. (Universitas Negeri Padang) Adri Febrianto, S.Sos., M.Si. (Universitas Negeri Padang) Drs. Ikhwan, M.Si. (Universitas Negeri Padang)

Dewan Penyunting:

Dr. EkaVidya Putra,S.Sos,.M.Si. Dr. Desy Mardiah,S.Sos.,S.Thi,.M.Si Ike Sylvia, S.IP,.M.Si

M. Isa Gautama,S.Pd,.M.Si. Reno Fernandes, S.Pd.,M.Pd.

\section{Layout Editor:}

Rhavy Ferdyan, S.Pd.

Technical Support:

Rudi Mahesa, A.Md.

Alamat Redaksi:

Jurusan Sosiologi FIS UNP

Jl. Prof.Dr.Hamka

Kampus UNP Air Tawar

e-mail: sosan@fis.unp.ac.id

\section{Penerbit}

Labor Jurusan Sosiologi

Universitas Negeri Padang
Artikel :

\section{DAFTAR ISI}

\section{Eka Vidya Putra}

Money Politics Dalam Penyelengaran Pemilihan Umum

Di Kota Pariaman

Halaman 1-16

Helpi Nelwatri

Upaya Preventif Masalah Kesehatan Reproduksi Remaja Melalui Media Informatif Buku Saku Kespro

Berbasis Budaya Lokal Untuk Orang Tua

Di Kabupaten Lima Puluh Kota

Provinsi Sumatera Barat

Halaman 17-21

\section{Junaidi}

Upaya Meningkatkan Kemampuan Peserta Didik Berpikir Kritis

Melalui Penerapan Srategi Pembelajaran Berbasis Masalah

Pada Pembelajaran Sosiologi Kelas XI IPS 2 SMA Negeri 1 Pariaman Halaman 22-30

Muhammad Hidayat

Problematika Internal Nelayan Tradisional KotaPadang:Studi FaktorFaktor Sosial Budaya Penyebab Kemiskinan

$$
\text { Halaman 31-40 }
$$

Mohammad Isa Gautama

Analisis Framing Pemberitaan Operasi Tangkap Tangan Patrialis Akbar

Di Media Daring Lokal Dan Nasional Halaman 41-49

\section{Nurlizawati}

Perceraian Secara Adat (Cerai Dusun)

Halaman 50-60 


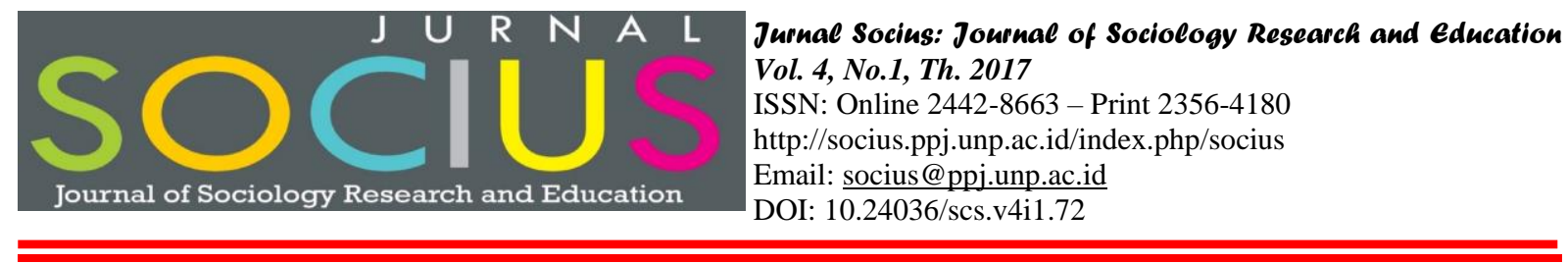

\title{
ANALISIS FRAMING PEMBERITAAN OPERASI TANGKAP TANGAN PATRIALIS AKBAR DI MEDIA DARING LOKAL DAN NASIONAL
}

\author{
Mohammad Isa Gautama \\ Universitas Negeri Padang \\ Email: mohammadisagautama@yahoo.co.uk
}

\begin{abstract}
Abstrak
Korupsi masih terus terjadi di tanah air, menjadi lahan pemberitaan utama oleh media, baik media konvensional, maupun new media, termasuk media dalam jaringan (daring). Korupsi dilakukan oleh koruptor mulai dari level terendah hingga tertinggi di puncak kekuasaan. Baru-baru ini, juga terjadi tindak korupsi yang dilakukan oleh salah satu hakim Mahkamah Konstitusi, Patrialis Akbar dan kroninya. Berita Operasi Tangkap Tangan (OTT) yang dilakukan oleh Komisi Pemberantasan Korupsi (KPK) telah menjadi sorotan utama sepanjang hari kejadian dan tidak luput dari pemberitaan oleh seluruh media, baik nasional maupun lokal, konvensional dan media baru. Penelitan ini menggunakan Analisis Wacana Kritis (AWK) melalui pendekatan Analisis Framing versi Robert N. Entman. Data yang dikumpulkan bersumber dari pemberitaan media daring nasional (detik.com), serta media daring lokal di Sumatera Barat (klikpositif.com). Pertanyaan utama studi adalah: Bagaimana proses seleksi berita serta penonjolan pada aspek tertentu dalam pemberitaan di masing-masing media? Kedua, posisi apa yang dipilih oleh media bersangkutan dalam hal pemberitaan kasus Patrialis Akbar sekaitan agenda pemberantasan korupsi di Indonesia dewasa ini? Temuan utama penelitian adalah, klikpositif.com tidak menjadikan berita OTT tindak korupsi sebagai berita paling penting di hari kejadian. Sebaliknya, detik.com secara provokatif memprioritaskan tema antikorupsi sebagai tema penting dalam pemberitaannya.
\end{abstract}

Kata Kunci: Korupsi, Media daring, Analisis framing, Posisi media

\section{Abstract}

Corruption continues to occur in our country, covered as headline by media, not only by main stream media, but also new media, including media in the network (On-line). Corruption has been doing by corruptors, ranging from the lowest to the top level of power. Recently, it also committed by one of the judges of the Constitutional Court, Patrialis Akbar and his cronies. News about Caught in the Act Operation (OTT) conducted by the Corruption Eradication Commission (KPK) has become a major focus throughout the day of the incident by media both national and local, conventional and new media. This research uses Critical Discourse Analysis (AWK) approach of Framing Analysis of Robert N. Entman version. The data collected from national online media (detik.com), as well as local online media in West Sumatra (klikpositif.com). The main question of the study is: How does the selection process as well as the protrusion on certain aspects of the news in each medium? Second, what position selected by the media concerned in terms of reporting cases of Patrialis Akbar regarding anti-corruption agenda in Indonesia today? The main finding of this research is, klikpositif.com do not make the news OTT-PA as the most important news on the day of the incident. Instead, detik.com provocatively priorityizes the theme of anti-corruption as the most important focus in its preaching.

Key Words: Corruption, On-line media, Framing analysis, Media position

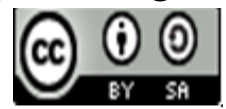

Received: January 8, 2017 Revised: April 14, $2017 \quad$ Available Online: June 22, 2017

Jurnal Socius: Journal of Sociology Research and Education Vol. 4, No.1, Th. 2017

ISSN: Online 2442-8663 - Print 2356-4180 


\section{Pendahuluan}

Hingga saat ini, korupsi masih merupakan problem krusial bagi negara kita. Tindak kriminal korupsi bagai menggurita di seluruh level, lintas profesi dan gender, dilakukan oleh kalangan sipil-militer, pejabat dan pengusaha, penegak hukum dan masyarakat biasa, pendidik dan tokoh masyarakat, bahkan para ulama dan rohaniwan. Mengutip Indrayana (2016: 1), sudah tidak perlu ditegaskan lagi, korupsi adalah masalah utama bangsa kita, meskipun negara ini telah merdeka, namun efek pembangunan belum dirasakan oleh banyak warga bangsa, karena korupsi merajajela.

Untuk mengukur seberapa memprihatinkan kondisi negara ini disebabkan oleh tindak korupsi, begitu banyak survey, baik dalam maupun luar negeri yang konsisten menggambarkan ranking Indonesia dari tahun ke tahun. Bisa dikatakan, hasil survey tersebut secara serempak menyuarakan kesimpulan bahwa meski sudah mengalami perbaikan, namun perubahannya belum signifikan. Salah satu lembaga yang paling sering dijadikan barometer mengenai hal ini bisa didapat dari data tahunan dari Transparancy International yang tidak pernah absen mengadakan survey serius secara global mengenai Indeks Persepsi Korupsi (IPK). Khusus Indonesia, data termutakhir, per-Januari 2017 menunjukkan bahwa negara kita (masih) menempati peringkat urutan 90 dari 176 negara yang diukur, mendapatkan poin sebesar 37 untuk tahun pengukuran 2016. Skor ini Cuma naik 1 poin dari tahun sebelumnya, 2015. Sebaliknya, secara peringkat justru turun dari peringkat ke-88 di tahun 2015.

Sekaitan usaha memerangi korupsi, Smilov (2007) menyebutkan ada enam elemen yang akan menjadi kekuatan ampuh sebagai katalisator gerakan anti korupsi. Keenam elemen itu adalah media, politikus, lembaga peradilan (yudikatif), kepolisian dan kejaksaan, masyarakatsipil/LSM, dan para pengusaha/pebisnis. Keenam elemen ini harus bisa bersinergi, memiliki agenda utama dalam setiap programnya untuk tidak saja membasmi kasus-kasus korupsi, namun juga mampu menerapkan preventif system (sistem yang mampu mencegah) di lembaganya masing-masing. Beranjak dari hal ini, tanpa menafikan lima elemen lainnya, media merupakan salah satu ujung tombak yang tidak diragukan lagi efeknya dalam mengkampanyekan gerakan antikorupsi. Apa pun yang diberitakan dan dipublikasikan oleh media, menyangkut tema antikorupsi, merupakan sarana edukasi bagi masyarakat akan bahaya korupsi. Terlebih, media memiliki empat fungsi, yang salah satunya adalah sebagai kontrol sosial di tengah masyarakat.

Beranjak dari hal di atas, konsep paradigma kaum konstruksionis seperti bertemu ruas dengan buku dengan usaha media (dalam hal ini media daring) dalam turut ambil bagian gerakan antikorupsi. Media, tak pelak, merupakan alat ampuh yang bisa dikonstruksi sedemikian rupa agar menjadi bagian dari kontrol sosial dalam meminimalisir 'tradisi' atau 'budaya korupsi' yang sudah demikian menggejala di tengah masyarakat Indonesia. Sebagai sebuah realitas sosial yang negatif, korupsi harus bisa diredam oleh media. Sejalan dengan paradigma yang disampaikan Peter D. Moss (1999, dalam Mulyana, 2002: x), wacana media massa, termasuk berita di surat kabar (dan juga media dalam jaringan, pen.), merupakan konstruk kultural yang dihasilkan ideologi karena, sebagai produk media massa, berita menggunakan kerangka tertentu untuk memahami realitas sosial.

Penelitian ini melandaskan teorinya pada paradigma konstruksionis yang terutama dipelopori oleh Berger, Luckman, dan Erving Goffman. Berger dan Luckmann mengatakan bahwa realitas sosial terdiri dari tiga macam; yaitu realitas subjektif, realitas objektif dan realitas simbolik. Realitas objektif adalah realitas yang terbentuk dari pengalaman di dunia objektif yang berada di luar diri individu, dan realitas ini dianggap sebagai kenyataan. Realitas simbolik merupakan ekspresi simbolik dari realitas objektif dalam berbagai bentuk, Sementara itu, realitas subjektif adalah realitas objektif dan simbolik ke dalam individu melalui proses internalisasi (Subiakto 1997, dalam Bungin, 2012). 
Tesis utama dari Berger adalah manusia dan masyarakat adalah produk yang dialektis, dinamis, dan plural secara terus menerus. Masyarakat tidak lain adalah produk manusia, namun secara terus-menerus mempunyai aksi kembali terhadap penghasilnya (Eriyanto, 2002: 13-14). Bagi Berger, realitas tidak dibentuk secara ilmiah, tidak juga sesuatu yang diturunkan oleh Tuhan. Tetapi sebaliknya, ia dibentuk dan dikonstruksi. Dengan pemahaman semacam ini, realitas berwajah ganda/plural. Setiap orang bisa mempunyai konstruksi yang berbeda-beda atas suatu realitas (Eriyanto, 2002: 15).

Sobur (2004) mengatakan, selain analisis framing, juga ada analisis isi agenda setting dan analisis semiotika sosial. Ketiganya masuk ke dalam kelompok paradigma konstruktivisme yang percaya bahwa apa pun yang dikemas dan ditampilkan oleh media merupakan hasil konstruksi dan campur tangan dari para aktor di belakangnya, dalam hal ini wartawan dan jurnalis sebagai pengolah berita. Lebih jauh, Menurut Sobur (2004; 162), analisis framing adalah pendekatan untuk mengetahui bagaimana perspektif atau cara pandang yang digunakan oleh wartawan ketika menyeleksi isu dan menulis berita.

Lebih konkrit, analisis framing secara sederhana dapat digambarkan sebagai analisis untuk mengetahui bagaimana realitas (peristiwa, aktor, kelompok, atau apa saja) dibingkai oleh media, pembingkaian tersebut tentu saja melalui proses konstruksi (Eriyanto, 2002: 3). Eriyanto menjelaskan lebih detail, realitas sosial dimaknai dan dikonstruksi dengan makna tertentu. Peristiwa dipahami dengan bentukan tertentu. Hasilnya, pemberitaan media atau pada sisi tertentu atau wawancara dengan orang-orang tertentu. Semua elemen tersebut tidak hanya bagian dari teknis jurnalistik, tetapi menandakan bagaimana peristiwa dimaknai dan ditampilkan.

Klasifikasi analisis framing berikutnya adalah berdasarkan model William A. Gamson, menurut Gamson fungsi framing adalah untuk menghubungkan wacana yang ada di media dengan pendapat umum yang sedang berkembang mengenai suatu peristiwa yang terjadi. Sementara model yang keempat, dikonsep oleh Zhongdang Pan dan Gerald M. Kosicki. Menurut Pan dan Kosicki, ada dua konsepsi dari framing yang saling berkaitan. Pertama, dalam konsepsi psikologis. Framing dalam konsepsi ini lebih menekankan pada bagaimana seseorang memproses informasi dalam dirinya. Framing berkaitan dengan struktur dan proses kognitif, bagaimana seseorang mengolah sejumlah informasi dan ditunjukkan dalam skema tertentu. Kedua, konsepsi sosiologis, pandangan sosiologis lebih melihat bagaimana konstruksi sosial atas realitas (Eriyanto, 2002: 252-253). Dalam pendekatan ini, perangkat framing dibagi ke dalam empat struktur besar, yaitu sintaksis, skrip, tematik, dan retoris.

Beranjak dari latar belakang, fenomena, permasalahan, konsep dasar, dan teori yang relevan di atas, maka dapat dirumuskan masalah yang akan dikaji dalam penelitian ini, yaitu bagaimana media dalam jaringan (on line media) menampilkan dan mengemas serta mengkonstruksi berita langsung (straight news) tentang Operasi Tangkap Tangan yang dilakukan oleh Komisi Pemberantasan Korupsi Republik Indonesia terhadap hakim Mahkamah Konstitusi, Patrialis Akbar, pada 26 Januari 2017. Sebagaimana diketahui, Patrialis Akbar adalah putra asli berasal dari Sumatera Barat, merupakan satu dari sedikit tokoh yang pernah berkiprah di tiga ranah trias politika; eksekutif, legislatif, dan yudikatif. Ia dilahirkan di Padang, Sumatera Barat, 31 Oktober 1958. Ia adalah seorang advokat dan politikus yang saat ditangkap dalam operasi tangkap tangan oleh KPK menjabat sebagai Hakim Konsti tusi Mahkamah Konstitusi Indonesia. Beranjak dari fakta ini, adalah menarik dan penting meneliti sejauh mana media daring di Sumatera Barat memberitakan kasus OTT terhadap Patrialis Akbar (selanjutnya ditulis PA), mengingat selama ini PA merupakan salah satu putra terbaik kebanggaan masyarakat etnis minang. Lebih jauh, penelitian ini berusaha melihat konstruksi realitas dalam media daring Sumbar yang bisa jadi diterpa bias primordialisme budaya Minang. 


\section{Metode Penelitian}

Tujuan penelitian adalah untuk mengetahui dan memahami sejauh mana aktor di balik penulisan berita membingkai dan mengkonstruksikan realitas berita yang ada. Model analisis framing yang dipilih dalam penelitian ini adalah versi Robert Entman. Framing Entman menekankan bagaimana proses seleksi dan penonjolan aspek tertentu tergambar dari realitas yang ditangkap dari pemberitaan media.

Analisis Framing versi Robert N. Entman dibagi menjadi empat elemen yaitu: Define Problems (pendefinisian masalah), yaitu bagaimana suatu peristiwa dilihat sebagai apa, Diagnose Causes (memperkirakan penyebab masalah), memperkirakan masalah atau sumber dari masalah, Make Moral Judgement (membuat pilihan moral), nilai moral apa yang ingin disajikan dalam berita, dan Treatment Recommendation (menekankan penyelesaian), yaitu penyelesaian apa yang ingin ditawarkan untuk mengatasi konflik tersebut (Eriyanto, 2002: 223)

Penelitian ini memilih corak kualitatif sebagai tipe penelitian. Menurut Moleong (2007: 4), metodologi kualitatif adalah metode penelitian yang berlandaskan pada kata-kata yang tertulis maupun secara lisan dari tindakan bisa yang dilihat. Peneliti menggunakan metode kualitatif dengan pendekatan deskriptif dikarenakan peneliti ingin menganalisa fenomena media dalam mengkonstruksi suatu kasus atau realitas dalam berita. Dalam hal ini, pemberitaan Operasi Tangkap Tangan Hakim Mahkamah Konstitusi, Patrialis Akbar pada pada 26 Januari 2017 merupakan objek penelitian. Pola penelitian yang digunakan dalam studi ini adalah deskriptif-analitis.

Untuk mengetahui bagaimana pemberitaan proses tangkap tangan terhadap PA dibingkai oleh media, peneliti mengambil teks pemberitaan dari dua media daring, masingmasing satu daring nasional, dan satu daring daerah, dalam hal ini media daring yang berkedudukan di Padang, Sumatera Barat. Kedua media daring dipilih terutama berdasarkan peringkat nasional dari situs alexa.com, yang dengan kontinu mengukur jumlah pengunjung yang mengakses seluruh media di dunia, baik media komersial, nonkomersial, dan media berita, setiap detiknya.

Dari data yang didapat alexa.com, maka detik.com merupakan media daring yang masuk ke dalam ranking 10 besar untuk skala nasional. Terbukti, detik.com menduduki peringkat 213 secara global, dan peringkat 6 secara nasional. Ini merupakan peringkat tertinggi untuk media daring berita. Di lain pihak, menilik urutan peringkat lalu lintas akses dan jumlah total pengunjung untuk media berita di Sumatera Barat, maka peringkat klikpositif.com termasuk paling tinggi, dengan mencapai ranking 1429 untuk nasional. Ada pun harianhaluan.com menduduki peringkat kedua di Sumbar, dengan menduduki ranking 2134 secara nasional, diikuti oleh hariansinggalang.co.id, yang menduduki peringkat 4006 secara nasional.

Teknik pengumpulan data yang dilakukan adalah dengan memilih pemberitaan straight news yang diunggah pada 26 Januari 2017 di dua media daring dimaksud. Sebagaimana diketahui, 26 Januari 2017 adalah hari di saat Komisi Pemberantasan Korupsi melakukan Operasi Tangkap Tangan terhadap PA di sebuah mall di Jakarta (kompas.com, 26/1/17).

Ada pun teknik analisis data pada penelitian ini adalah dengan membaca secara umum dan sekaligus seksama generalisasi pemberitaan di kedua media daring. Sebagaimana dikatakan Eriyanto (2002: 186), Entman melihat framing dalam dua dimensi besar: seleksi isu dan penekanan atau penonjolan aspek-aspek tertentu dari realitas/isu. Penonjolan adalah proses membuat informasi menjadi lebih bermakna, lebih menarik, berarti, atau lebih diingat oleh khalayak. Selanjutnya, dalam konsepsi Entman, framing pada dasarnya merujuk pada pemberian definisi, penjelasan, evaluasi, dan rekomendasi dalam suatu wacana untuk 
menekankan kerangka berpikir tertentu terhadap peristiwa yang diwacanakan (Eriyanto, 2002: 188).

\section{Hasil dan Pembnahasan}

\section{Hasil Penelitian}

Pada temuan data awal, terdapat sangat banyak jumlah total straight news yang diunggah di media daring nasional, detik.com, yaitu sebanyak 64 buah pemberitaan yang menyoal sejak dari desas-desus OTT-PA, sampai hal-hal lain yang tidak terlalu berhubungan langsung dengan peristiwa inti. Sebaliknya, media daring Sumatera Barat, klikpositif.com hanya mengunggah sebanyak 2 berita seputar OTT-PA pada 26/1/2017. Jika pun ditambah dengan hari berikutnya, total pemberitaan selama dua hari di klikpositif.com tentang OTT-PA adalah sebanyak 4 berita.

Peneliti akhirnya menyeleksi empat berita saja dari berita yang ada dari masing-masing media daring, masing-masing 4 dari detik.com dipilih dari hari yang sama saat OTT-PA terjadi. Untuk berita klikpositif.com, peneliti terpaksa menambahkan 2 berita di hari berikutnya (27/1/17) untuk menjadikanya memiliki jumlah yang sama dengan berita detik.com. Pertimbangan pemilihan fokus pada beberapa aspek. Aspek pertama, berita yang dijadikan sumber analisis penelitian adalah berita yang benar-benar mendeskripsikan peristiwa inti seputar penelitian, yaitu seputar OTT-PA. Aspek kedua, peneliti memilih berita yang dari segi waktu pengunggahannya berdekatan dan mewakili rentang waktu selama 24 jam. Untuk itu, peneliti berusaha merepresentasi berita melalui pengelompokan ke dalam empat titik krusial sejak awal peristiwa mulai diendus oleh jurnalis sampai di menit-menit terakhir pemberitaan yang dikover oleh media bersangkutan pada hari tersebut. Aspek ketiga, peneliti memilih dan memilah berita yang menggambarkan keunikan masing-masing media dalam pemilihan dan penonjolan angel/sudut pemberitaan. Jika ditemukan keunikan dan atau perbedaan dari masing-masing media, atau antara media nasional dan lokal, maka peneliti akan menjadikannya objek kajian penelitian. Ini sangat relevan dengan tujuan penelitian, yaitu dalam rangka mengetahui dan memahami seleksi isu dijalankan oleh masing-masing media, sesuai dengan konsepsi analisis framing versi Robert Entman.

Berdasarkan klasifikasi yang berpedoman pada aspek argumentatif dalam bab metodologi penelitian di atas, maka dari proses pemilihan dan pemilahan berita straight news yang dilakukan oleh peneliti didapat daftar judul berita berikut menit tampil di saat pengunggahannya di masing-masing media daring sebagai berikut:

Tabel 1. Daftar Judul Berita (26/1/17 dan 27/1/17) yang Menjadi Objek Penelitian

\begin{tabular}{llll}
\hline NO. & \multicolumn{1}{c}{ DETIK.COM } & \multicolumn{1}{c}{ KLIKPOSITIF.COM } \\
\hline 1 & $\begin{array}{l}\text { Suap untuk Patrialis Akbar Terkait Uji } \\
\text { Materi UU Peternakan (15: 36) }\end{array}$ & $\begin{array}{l}\text { KPK: OTT Patrialis Akbar Menyangkut } \\
\text { Lembaga Hukum (15:34) }\end{array}$ \\
\hline 2 & $\begin{array}{l}\text { Patrialis Akbar Ditangkap KPK: } \\
\text { Penggugat Angkat Bicara (19:26) }\end{array}$ & $\begin{array}{l}\text { Keluarga Patrialis di Padang Akan Terbang } \\
\text { ke Jakarta (19: 18) }\end{array}$ \\
\hline 3 & $\begin{array}{l}\text { Perantara Suap Uji Materi UU } \\
\text { Peternakan Merupakan Rekan Patrialis }\end{array}$ & Ini Ternyata Suap yang Diterima Patrialis \\
& Akbar (13:00) & \\
& $(20: 08)$ & & \\
\hline 4 & $\begin{array}{l}\text { KPK: Suap yang Diterima Patrialis } \\
\text { Akbar Sudah Ketiga Kalinya (20:30) }\end{array}$ & Ternyata, Sebelum Jadi Hakim MK \\
& & &
\end{tabular}




\section{Pembahasan}

Sebagaimana kita simak di tabel di atas, ada sebanyak total 8 judul berita yang dijadikan objek analisis penelitian, 4 diunduh dari detik.com, 4 lainnya dari klikpositif.com. Berhubung klikpositif.com hanya merilis 2 berita sepanjang 26 Januari 2017, maka dua berita di keesokan harinya, yang masih relevan dan bicara mengenai OTT-PA akhirnya ikut diikutkan sebagai bagian dari objek penelitian. Masing-masing berita dikelompokkan pembahasannya berdasarkan media daring yang mengunggah berita. Selanjutnya, masingmasing berita dibahas berdasarkan empat aspek pembingkaian versi Entman, yaitu Problem Identification, Causal Intrerpretation, Moral Evaluation, dan Treatment Recommendation.

\section{Framing detik.com}

Problem Identification. Detik.com sepanjang 26/1/17 menjadikan OTT-PA sebagai berita utamanya, terbukti dari 64 berita dirilis dalam waktu 24 jam. Meski hanya 4 di antaranya yang dijadikan bahan analisis, keempatnya menyiratkan bahwa detik.com megidentifikasi OTT-PA sebagai sebuah berita besar yang sangat layak dijadikan berita utama. Memulai pertama kali memberitakaan kasus OTT-PA pada pukul 10:06 WIB, detik.com tak henti untuk fokus membeberkan berbagai hal. Terkait berita pertama yang dijadikan analisis temuan penelitian yang bertajuk 'Suap untuk Patrialis Akbar Terkait Uji Materi Peternakan', detik.com memaparkan termuannya yang menyasar bagian paling inti peristiwa OTT-PA, dan itu seolah mewakili KPK dalam hal menjawab pertanyaan utama dari publik, yaitu 'Mengenai hal-ihwal apakah suap yang diterima PA sehingga ia terjerembab dalam OTT?'. Berita ini dengan gamblang mencoba menjawab pertanyaan itu. Berita kedua dan ketiga merupakan penegasan yang lebih detail perihal orang-orang di sekeliling PA yang berkepentingan dengan kasus yang menjadi sumber penyuapan. Berita kedua menyasar tentang penggugat, sementara berita ketika menjelaskan bahwa penyuap ternyata bukanlah orang lain melainkan rekan PA. Berita keempat, 'KPK: Suap yang Diterima Patrialis Sudah Ketiga Kalinya', memperkuat gambaran bahwa detik.com mengidentifikasi peristiwa OTTPA sebagai sebuah problem besar, menyangkut betapa bobroknya integritas salah seorang hakim Mahkamah Konstitusi ini.

Causal Interpretation. Tak bisa dibantah, detik.com sedari awal menempatkan PA sebagai 'biang kerok' kegaduhan politik tingkat tinggi sepanjang 26 Januari 2017. Berbagai sisi penting sekaitan OTT diangkat sebagai straight news, pemberitaannya menempatkan PA sebagai hakim sebuah institusi paling dihormati di Indonesia saat ini yang telah mengkhianati kepercayaan publik. PA juga kerap dituding tidak bisa menjaga amanah, tidak mampu belajar dari kasus yang pernah menjerat ketua MK di periode sebelumnya, Akil Mochtar, yang terlibat penyuapan jual beli kasus juga di tahun 2013 lalu.

Moral Evaluation. Tidak bisa dipungkiri, detik.com dalam 64 pemberitaan mengenai OTT-PA, juga pada 4 berita yang dinalisis dalam penelitian ini, masalah moral menjadi salah satu titik fokus yang menempatkan PA sebagai tokoh publik yang tidak lagi mengedepankan moral sebagai filter dan benteng segala tindak-tanduknya. Berita keempat yang dianalisis, menjelaskan kepada publik bahwa PA ternyata tidak melakukan tindakan suap ini sebagai sebuah tindakan perdana, melainkan sudah untuk yang ketigakalinya.

Treatment Recommendation. Detik.com merekomendasikan agar kasus OTT-PA diproses dengan mempertimbangkan berbagai aspek. Aspek-aspek itu mayoritas memberatkan PA. Ini menegaskan sekali lagi bahwa media ini mengutuk keras tindakan memalukan seorang PA, dan mengajak KPK sebagai ujung tombak utama pemberantasan korupsi di tanah air untuk tetap objektif dan tidak terpengaruh berbagai tekanan yang bisa jadi mengaburkan dan mendegradasi semangat antikorupsi. 


\section{Framing klikpositif.com}

Problem Identification. Tidak terdapat alasan yang kuat untuk mengatakan bahwa klikpositif.com berkomitmen untuk mengedukasi masyarakat tentang betapa parahnya kondisi kasus-kasus korupsi di tanah air. Identifikasi yang dilakukan oleh media ini sangat minim dalam hal menyorot OTT-PA sebagai salah satu kasus besar di awal tahun 2017 dalam hal tidnak korupsi. Relatif hanya di berita pertama, yang berjudul 'KPK: OTT Patrialis Akbar Menyangkut Lembaga Hukum', klikpositif.com mencoba membangun imej bahwa media ini bersama-sama dengan KPK memiliki komitmen yang senada dalam pemberantasan korupsi. Sementara di tiga berita berikutnya, kesan yang didapat publik adalah betapa klikpositif.com seolah mencoba mengalihkan isu kepada hal-hal 'remeh', yaitu seputar keberangkatan keluarga PA yang berangkat ke Jakarta, dan kesan bahwa media ini seperti 'ketinggalan kereta' mengenai substansi suap yang diterima PA. Berita terakhir, 'Ternyata, Sebelum Jadi Hakim MK Patrialis Akbar Pernah Jadi Sopir', justru membelokkan perhatian publik pada kasus OTT-PA. Tema latarbelakang masa lalu PA ditonjolkan seakan-akan dengan harapan publik lupa bahwa itu tidak ada hubungannya dengan tindak penyuapan yang dialami PA.

Causal Interpretation. Tidak tampak penegasan yang konkrit mengenai posisi klikpositif.com terhadap PA sebagai penyebab kegaduhan yang ditimbulkannya. Tidak ada satu berita pun yang menyadarkan publik bahwa PA telah mengkhianati amanah seluruh elemen bangsa untuk menjadi bagian terdepan menyuarakan dan mempraktikkan nilai-nilai demokrasi.

Moral Evaluation. Tidak jauh beda dengan analisis di atas, klikpositif.com sangat minim menempatkan standar moral sebagai acuan pemberitaan sekaitan OTT-PA. Ada kesan bahwa media ini berusaha menghindari resistensi dari khalayak yang sebagian besar adalah masyarakat etnis minang. Bisa jadi, ada unsur primordialisme semu yang merasa malu atau bahkan tabu untuk menyudutkan tokoh sekelas PA yang selama ini dikenal sebagai 'bersih' dan 'antikorupsi', serta berhasil menjaga marwah dan nama baik kaum bersuku bangsa minang.

Treatment Recommendation. Klikpositif.com tidak menampakkan himbauan atau saran secara simbolis melalui pemberitaannya sekaitan OTT-PA. Rekomendasi yang diharapkan secara tegas menyatakan perang terhadap korupsi itu seolah 'terhimpit' oleh tema-tema 'ringan' berupa pembelokan angel/sudut pandang pemberitaan. Substansi bahwa korupsi merupakan bahaya yang nyata dan mengancam seluruh sendi kehidupan bangsa tidak tercermin dari pemberitaan mengenai OTT-PA.

\section{Penutup}

Dalam perspektif konstruktivisme, media merupakan produk dari ideologi dan kepercayaan sosiokultural dari pengelola dan pemiliknya. Entman (2010: 337) mengatakan bahwa bias media semakin kuat manakala berbagai kepentingan berebut pengaruh untuk memenangkan hati publik. Media yang memiliki kesadaran tanggung jawab sosial yang tinggi akan bisa menahan bias itu dengan syarat selalu melakukan evaluasi dan 'pembersihan' terhadap potensi ancaman kepentingan apa pun yang dengan mudah datang tanpa diduga.

Bias yang bersembunyi dalam teknik pembingkaian (framing) berita, terutama media lokal, akan menyebabkan masyarakat tidak mendapatkan pegangan moral dan arah komitmen yang pasti tentang bagaimana seharusnya endemik korupsi mesti diperangi secara masif dan kolektif. Dalam tataran ini, media daring lokal di Sumatera Barat sedang diuji objektivitasnya dalam menyikapi berbagai kasus dan kemungkinan kasus serupa di masa mendatang, karena terbukti dalam pemberitaan kasus korupsi cenderung tidak setajam media daring nasional. 


\section{Daftar Pustaka}

Alexa.com. Diakses 5 Februari 2017, pukul 19.43.WIB

Bungin, Burhan. (2008). Konstruksi Sosial Media Massa: Kekuatan Pengaruh Media Massa

Iklan Televisi dan Keputusan Konsumen serta Kritik Terhadap Peter L. Berger dan Thomas Luckmann. Jakarta: Kencana Prenada Media Group.

Bungin, Burhan, ed. (2012). Metodologi Penelitian Kualitatif: Aktualisasi Metodologis ke Arah Ragam Varian Kontemporer. Depok: PT. Raja grafindo Persada.

Bungin, Burhan. (2012). Realitas Sosial dan Konstruksi Sosial, dalam buku Metodologi Penelitian Kualitatif: Aktualisasi Metodologis ke Arah Ragam Varian Kontemporer. Depok: PT. Rajagrafindo Persada

Dahlgren, Peter. (1999). Television News Narrative. Dalam Mary S.mander (ed.). Framing Friction. Urbana: University of Illinois Press.

D’Angelo, Paul, and Jim A. Kuypers. (2010). Doing News Framing Analysis. New York and London: Routledge. Detik.com/indeks/berita. Diakses 4 Februari 2017, pukul 20.30 WIB.

Entman, Robert M. (2010). Framing Media Power. A chapter in Doing News Framing Analysis. New York and London: Routledge.

Eriyanto.(2002). Analisis Framing: Konstruksi, Ideologi, dan Politik Media. Yogyakarta: LKiS.

Hamad, Ibnu. (2004). Konstruksi Realitas Politik dalam Media Massa. Granit, Jakarta

Indrayana, Denny. (2016). Jangan Bunuh KPK. Malang: Intrans Publishing.

Kompas.com. Patrialis Akbar Ditangkap Bersama Seorang Perempuan di Grand Indonesia. 26 Januari 2017.

Klikpositif.com/indeks/berita. Diakses 4 Februari 2017

Mochtar, Zainal Arifin. (2016). Pemberantasan (Anti) Korupsi. Kata Pengantar untuk buku

Jangan Bunuh KPK, oleh Denny Indrayana. Malang: Intrans Publishing

Mulyana, Deddy. (2002). Analisis Framing: Suatu Pengantar. Kata Pengantar untuk buku Analisis Framing: Konstruksi, Ideologi, dan Politik Media, oleh Eriyanto. Yogyakarta: LKiS.

Robertson-Snape, Fiona. (1999). "Corruption, Collusion, and Nepotism in Indonesia." Third World Quarterly. June, Vol.20, No.3: 589-602.

Schütte, Sofie Arjon. (2011). Appointing Top Officials In A Democratic Indonesia: The Corruption Eradication Commission. Bulletin of Indonesian Economic Studies, Vol. 47, No. 3, 2011: 355-79

Smilov, Daniel and Jurij Toplak (eds.). (2007). Political Finance and Corruption in Eastern Europe: The Transition Period. Hampshire England: Ashgate Publishing Limited.

Sobur, Alex. (2004). Analisis Teks Media, Bandung: PT Remaja Rosdakarya.

Ti.or.id. (Transparency Indonesia). Diakses 4 Februari 2017, pukul 22.30 WIB. 
Van Dijk, Teun A, ed. (1997). Discourse as Structure and Process. London: Sage Publications. 